\title{
Bioremediation and Detoxification of a Textile Azo Dye-Evans Blue by Bacterial Strain AKIP-2
}

\author{
S. Aswin Kumar ${ }^{1}$, N. Arunagirinathan ${ }^{2}$, S. Vijayanand ${ }^{3}$, J. Hemapriya ${ }^{4}$ and V. Indra ${ }^{1}$ * \\ ${ }^{1}$ Department of Zoology, ${ }^{2}$ Department of Microbiology, Presidency College, \\ Chennai, Tamilnadu, India \\ ${ }^{3}$ Department of Biotechnology, Thiruvalluvar University, Vellore, Tamilnadu, India \\ ${ }^{4}$ Department of Microbiology, DKM College, Vellore, Tamilnadu, India \\ *Corresponding author:
}

\begin{tabular}{|c|c|}
\hline & A B S T R A C T \\
\hline & Increasing industrialization and urbanization result in the discharge of waste to the \\
\hline $\begin{array}{l}\text { K e y w o r d s } \\
\text { E. coli strain } \\
\text { AKIP-2, } \\
\text { Evan's Blue, } \\
\text { Textile effluents }\end{array}$ & $\begin{array}{l}\text { environment, which in turn creates more pollution. Environmental biotechnology is } \\
\text { constantly expanding its efforts in the biological treatment of colored textile effluents, } \\
\text { which is an environmental friendly and low cost alternative to physico-chemical } \\
\text { decomposition processes. In the present study, effluent samples were collected from } \\
\text { various textile and dyeing industries located in and around Kanchipuram, Tamilnadu, India } \\
\text { and were exploited for the screening and isolation of bacterial strains that were capable of }\end{array}$ \\
\hline Article Info & decolorizing the textile dye, Evans Blue. Optimization of cultural conditions (Temperature, \\
\hline $\begin{array}{l}\text { Accepted: } \\
\text { 25 March } 2017 \\
\text { Available Online: } \\
10 \text { April } 2017\end{array}$ & $\begin{array}{l}\text { growth of } E \text {. coli strain AKIP- } 2 \text { and its decolorization efficiency towards Evans Blue. Both } \\
\text { bacterial biomass and decolorization efficiency was found to be optimized at } 35^{\circ} \mathrm{C} \text {, neutral } \\
\mathrm{pH} \text {, after } 24 \mathrm{~h} \text { of incubation. Static conditions proved to be effective in maximizing } \\
\text { decolorization. Increase in dye concentration decreased both bacterial growth and } \\
\text { decolorization efficiency of } E \text {. coli strain AKIP-2. }\end{array}$ \\
\hline
\end{tabular}

\section{Introduction}

Textile industry has a major impact not only on the nation's economy but also on the environmental quality of life in many communities. Textile manufacturing consumes a considerable amount of water approximately 100 litres of $\mathrm{H}_{2} \mathrm{O} \mathrm{kg}^{-1}$ of textile materials in its dyeing, finishing and manufacturing processes (Tang and Chen, 1996). Considering both the volume generated and the effluent composition, the textile industry wastewater is rated as the most polluting source among all industrial sectors (Koyuncu, 2002). Strong color of the textile wastewater is the most serious problem of textile waste effluent. The disposal of these wastes into receiving water causes damage to the environment (Shyamala et al., 2014). Dyes may significantly affect the photosynthetic activity in aquatic life because of reduced light penetration and may also be toxic to some aquatic life due to the presence of aromatics, metals, chlorides etc, (Husseiny, 2008; Hemapriya et al., 2010). In addition to their visual effect and adverse impact in terms of chemical oxygen demand (COD), many synthetic dyes show their toxic, carcinogenic 
and genotoxic effects (Pearce et al., 2003). Traditional wastewater treatment technologies have proven to be markedly ineffective for handling wastewater of synthetic textile dyes because of the chemical stability of these pollutants. Color is one of the most obvious indicators of water pollution and the discharge of highly colored synthetic dyes in textile effluents can be damaging to the receiving water bodies (Nigam et al., 1996; Shyamala et al., 2014). Implementation of physical/chemical methods have inherent drawbacks of being economically unfeasible (more energy consumption and chemical uses), unable to remove the recalcitrant azo dyes and/or their organic metabolites completely, generating a significant amount of sludge that may cause secondary pollution problems (Zhang et al., 2004; Hemapriya and Vijayanand, 2014). The microbial decolorization and degradation of azo dyes has been of considerable interest since it is inexpensive, eco-friendly and produces a less amount of sludge (Kalyani et al., 2008; Saratale et al., 2009). The effectiveness of microbial decolorization depends on the adaptability and the activity of selected microorganisms including bacteria, actinomycetes, fungi, yeasts, and algae capable of degrading azo dyes (Shyamala et al., 2014).

Hence, the present investigation was intended to assess the potential of AKIP-2 strain to decolorize the synthetic textile azo dye, Evans Blue under aerobic conditions, and to optimize the culture conditions to maximize the biomass and decolorization efficiency of AKIP-2 Strain.

\section{Materials and Methods}

\section{Sampling site and sample collection}

The sampling area was the textile industries and dyeing units located in and around
Kanchipuram, Tamil Nadu, India. The effluent samples from both textile industries and dyeing units were characterized by its dark color and extreme turbidity.

\section{Azo dye used}

The commonly used textile azo dye, Evans Blue used in this study was procured from a local textile dyeing unit. Stock solution was prepared by dissolving $1 \mathrm{~g}$ of Evans Blue in $100 \mathrm{ml}$ distilled water. The dye solution was sterilized by membrane filtration, since azo dyes may be unstable to moist-heat sterilization.

\section{Isolation and screening of bacterial strains decolorizing evans blue}

Effluent samples were serially diluted and spread over basal nutrient agar medium containing $50 \mathrm{ppm}$ of Evans Blue. Colonies surrounded by halo (decolorized) zones were picked and streaked on nutrient agar plates containing Evans Blue. Different colonies of dye decolorizing bacteria were picked and restreaked several times to obtain pure cultures.

\section{Decolorization assay}

A loopful of bacterial culture AKIP-2 was inoculated in $100 \mathrm{ml}$ of nutrient broth and incubated at $150 \mathrm{rpm}$ at $37^{\circ} \mathrm{C}$ for $24 \mathrm{~h}$. Then, $1 \mathrm{ml}$ of $24 \mathrm{~h}$ old culture was inoculated in 100 $\mathrm{ml}$ of nutrient broth containing $50 \mathrm{ppm}$ of Evans Blue and re-incubated at $37^{\circ} \mathrm{C}$ till complete decolorization occurs. Suitable control without any inoculum was also run along with experimental flasks. $1.0 \mathrm{ml}$ of sample was withdrawn every $12 \mathrm{~h}$ and centrifuged at $10,000 \mathrm{rpm}$ for $15 \mathrm{~min}$. Decolorization extent was determined by measuring the absorbance of the culture supernatant at $590 \mathrm{~nm}$ using UV-visible spectrophotometer (Hitachi U 2800), according to Hemapriya et al., (2013). 
Decolorization efficiency $(\%)=$ Dye $(i)-$ Dye (r) / Dye (i) $\times 100$

Where, Dye (i) refers to the initial dye concentration and Dye (r) refers to the residual dye concentration. Decolorization experiments were performed in triplicates.

\section{Bacterial strain and culture conditions}

Bacterial strain that showed maximum decolorization percentage on Evans Blue was aerobically cultured in nutrient broth containing $50 \mathrm{ppm}$ of Evans Blue. The $\mathrm{pH}$ was adjusted to 7.0. For frequent use, the culture was maintained by transfer to a fresh medium at $24 \mathrm{~h}$ intervals. When required for prolonged periods, it was maintained by subculturing once every 7 days on slants, prepared by solidifying the above mentioned medium with $2.0(\mathrm{w} / \mathrm{v})$ agar.

Optimization of various culture conditions for bacterial biomass and evans blue decolorization by AKIP-2

\section{Effect of temperature, $\mathrm{pH}$, agitation rates and dye concentrations}

The effect of temperature, $\mathrm{pH}$, agitation rates and dye concentration on both bacterial biomass and dye decolorizing ability of AKIP-2 strain was studied. This was carried out by incubating the bacterial strain at different temperatures $\left(20-60^{\circ} \mathrm{C}\right)$, different $\mathrm{pH}$ values of the medium ( $\mathrm{pH} 4.0-10.0)$, different agitation speeds $(0-200 \mathrm{rpm})$ and various dye concentrations (200-1000 ppm). Bacterial biomass and decolorization percentage was measured at optimum growth $(24 \mathrm{~h})$.

\section{Results and Discussion}

\section{Effect of incubation time}

Incubation time played a significant role in maximizing both bacterial growth and dye decolorizing ability of E.coli strain AKI-2. Results of the present study revealed that the dye decolorizing ability of the isolate was dependent on the bacterial growth. The bacterial cells started multiplying within $4 \mathrm{~h}$ and reached their maximum growth within 24 $\mathrm{h}$ and thereafter started to decline, due to the depletion of nutrients and accumulation of toxic metabolites (Fig 1 and 2). In contrast, decolorization of Methyl orange by Bacillus sp. strain TVU-M4 was achieved after $32 \mathrm{~h}$ of incubation (Shyamala et al., 2014).

\section{Effect of temperature}

The results shown in Fig 3 and 4 revealed that E.coli strain AKI-2 showed strong decolorizing activity and highest bacterial growth from $30-40^{\circ} \mathrm{C}$, with optimum being $35^{\circ} \mathrm{C}$ after $24 \mathrm{~h}$ of incubation. The incubation at 30,50 and $60^{\circ} \mathrm{C}$ was found to decrease both bacterial biomass and dye decolorizing ability of the bacterial strain; however the decolorization percentage of the isolate was found to be greatly inhibited at temperature below $30^{\circ} \mathrm{C}$. Decolorization of Congo Red by Bacillus sp. VT-II was maximized at $40^{\circ} \mathrm{C}$ (Sawhney and Kumar, 2011).

\section{Effect of pH}

E. coli strain AKI-2 grew well in a broad range of $\mathrm{pH}$ (5.0-10.0) and its decolorizing ability does not have strict $\mathrm{pH}$ requirement. Bacterial biomass and dye decolorizing ability was found to be optimized at neutral $\mathrm{pH}$ (7.0) (Fig.5 and 6). Similarly, neutral $\mathrm{pH}$ was found to be effective in maximizing both bacterial growth and dye decolorization efficiency of many bacterial strains.

The $\mathrm{pH}$ tolerance of the decolorizing bacteria is quite important because the reactive azo dyes bind to cotton fibers by the addition or substitution mechanisms under alkaline conditions (Aksu et al., 2007). 
Fig.1 Effect of incubation time on bacterial biomass of E. coli strain AKI-2

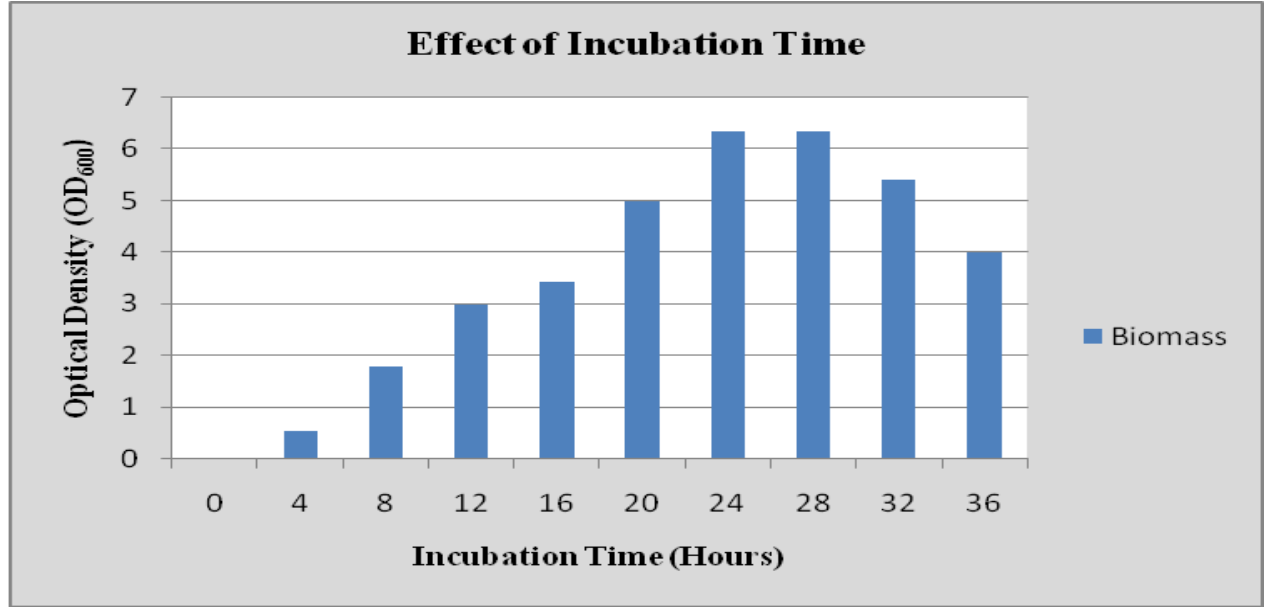

Fig.2 Effect of incubation time on decolorization of evans blue by E. coli strain AKI-2

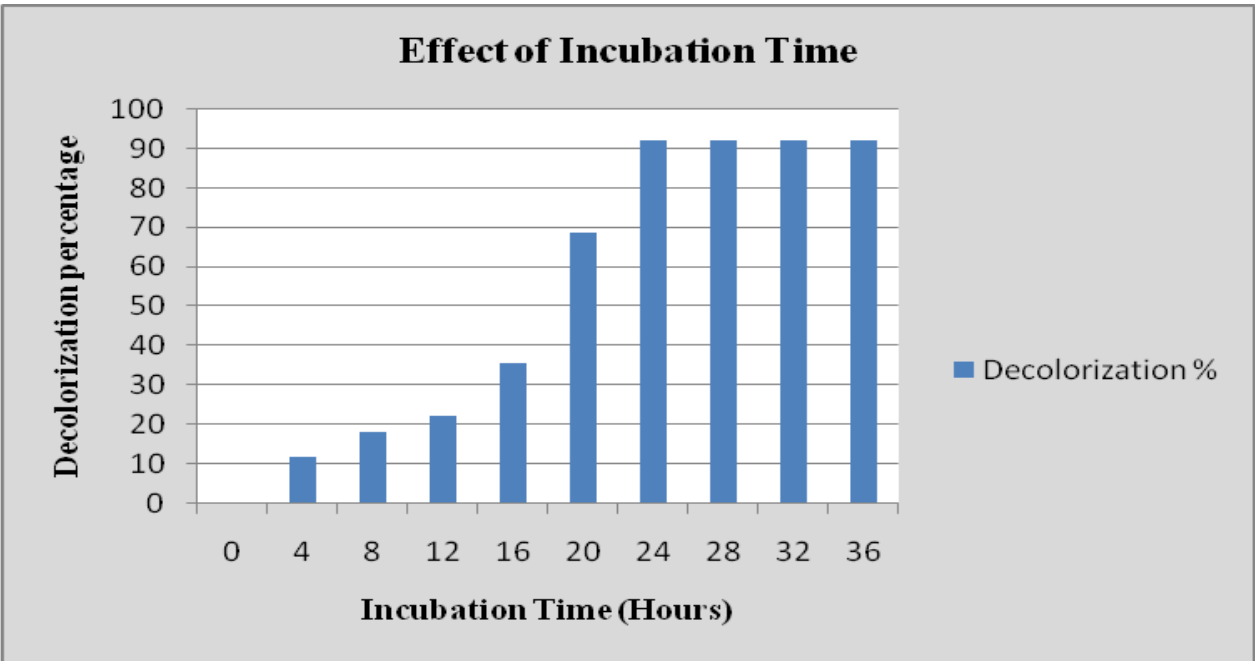

Fig.3 Effect of temperature on bacterial biomass of E. coli strain AKI-2

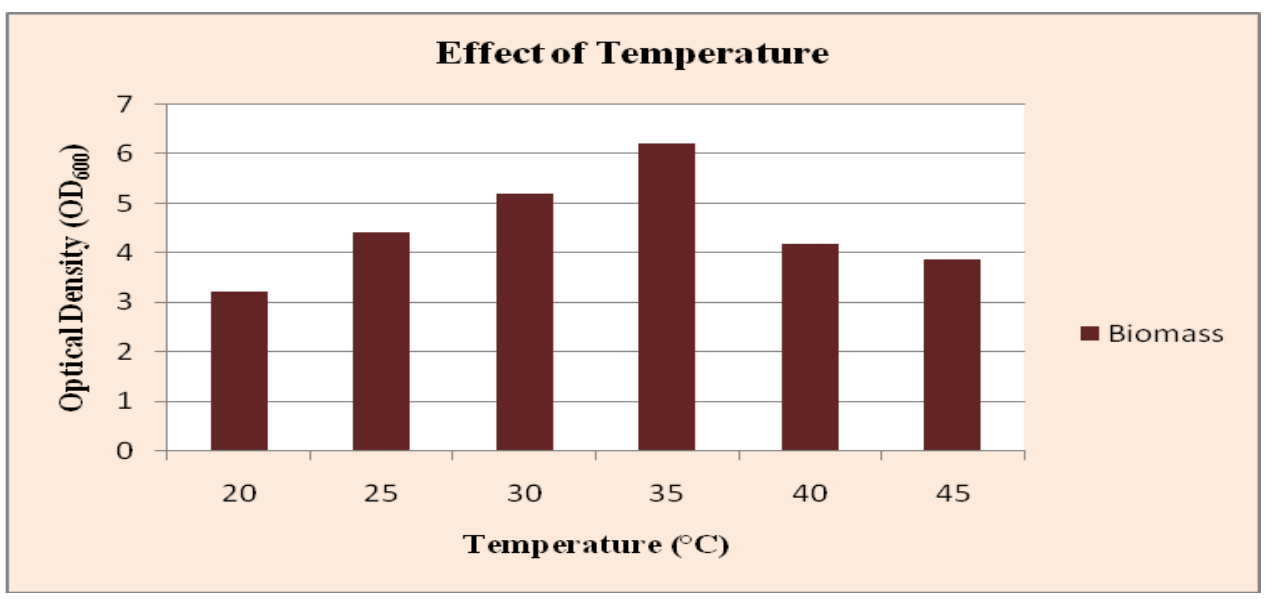


Fig.4 Effect of incubation time on decolorization of evans blue by E. coli strain AKI-2

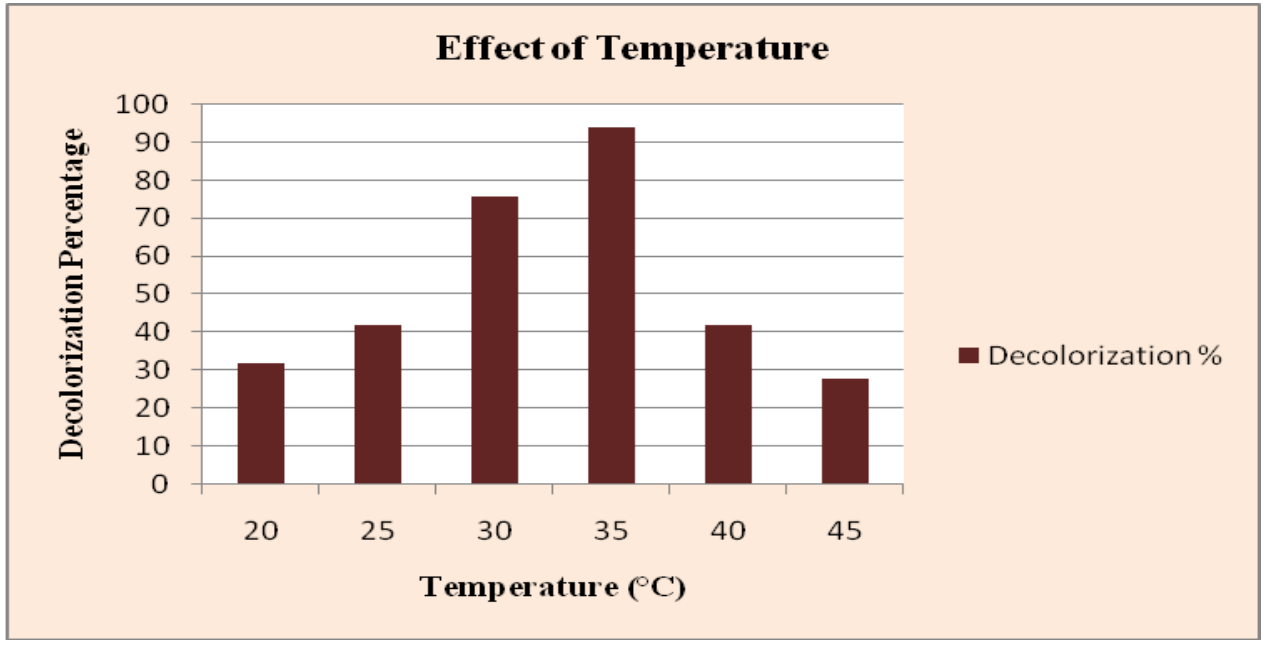

Fig.5 Effect of pH on bacterial biomass of E. coli strain AKI-2

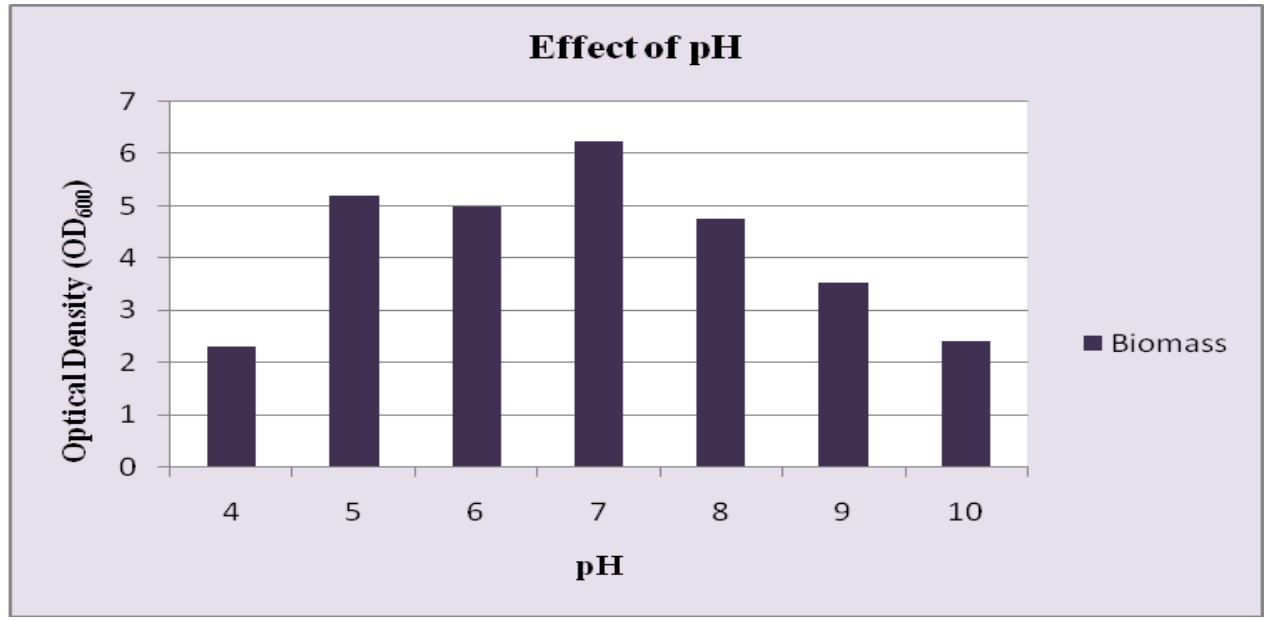

Fig.6 Effect of $\mathrm{pH}$ on decolorization of evans blue by E. coli strain AKI-2

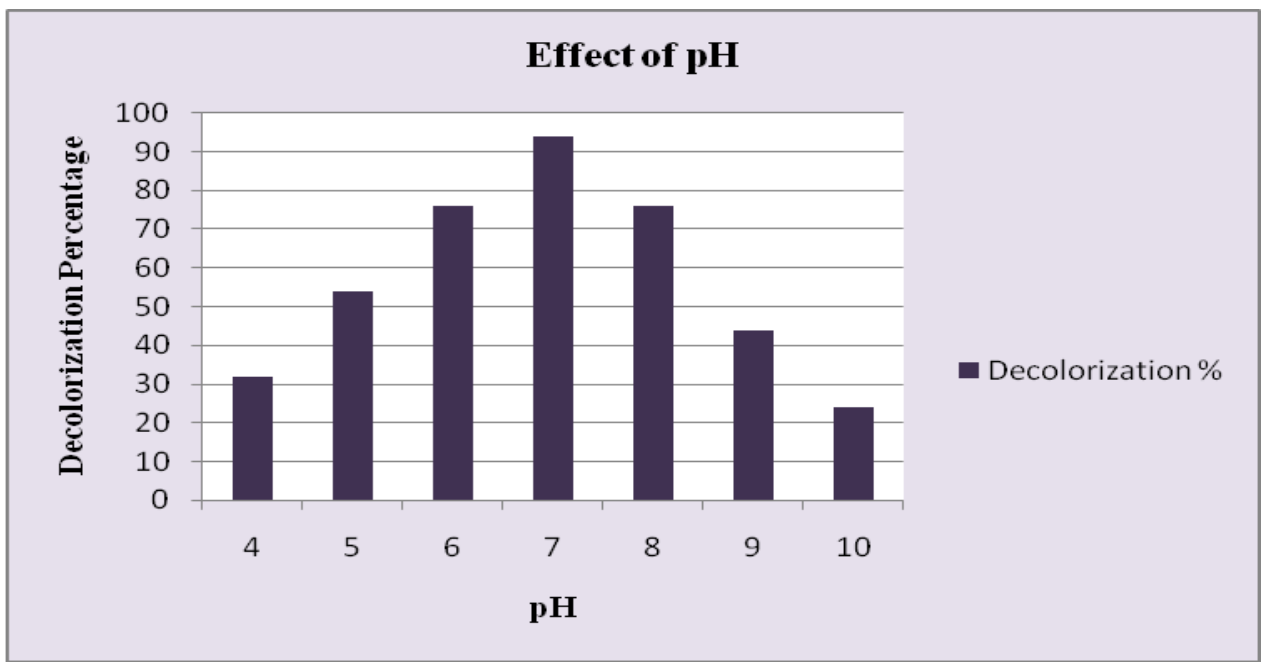


Fig.7 Effect of agitation speed on bacterial biomass of E. coli strain AKI-2

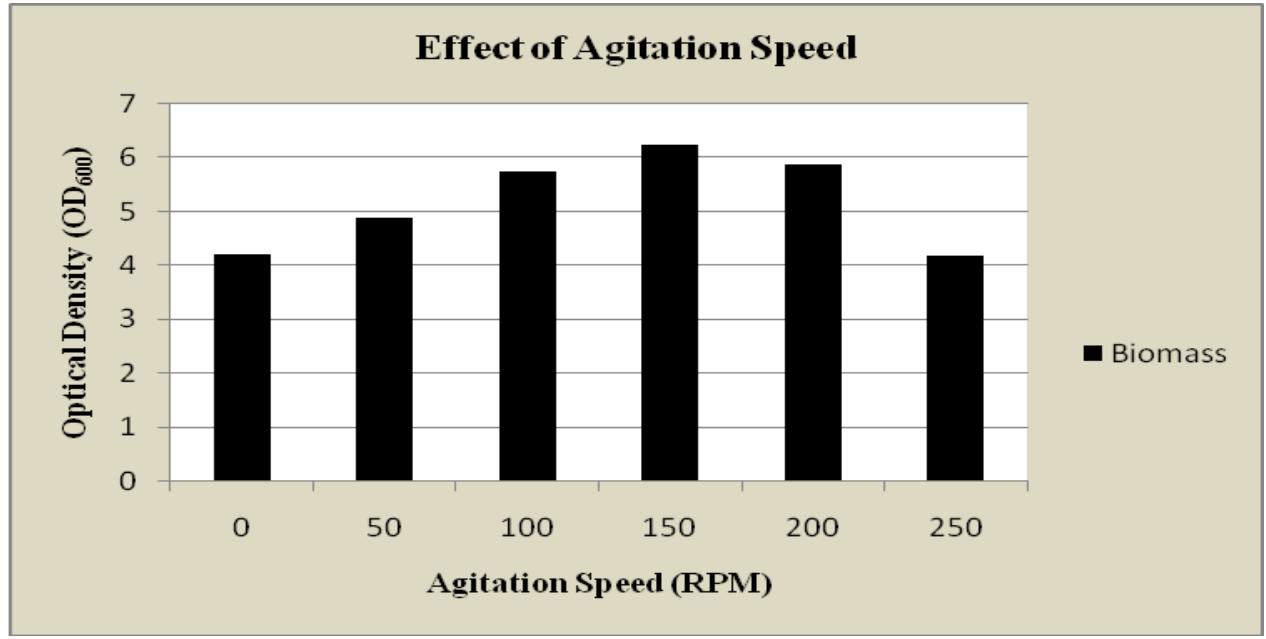

Fig.8 Effect of agitation speed on decolorization of evans blue by E. coli strain AKI-2

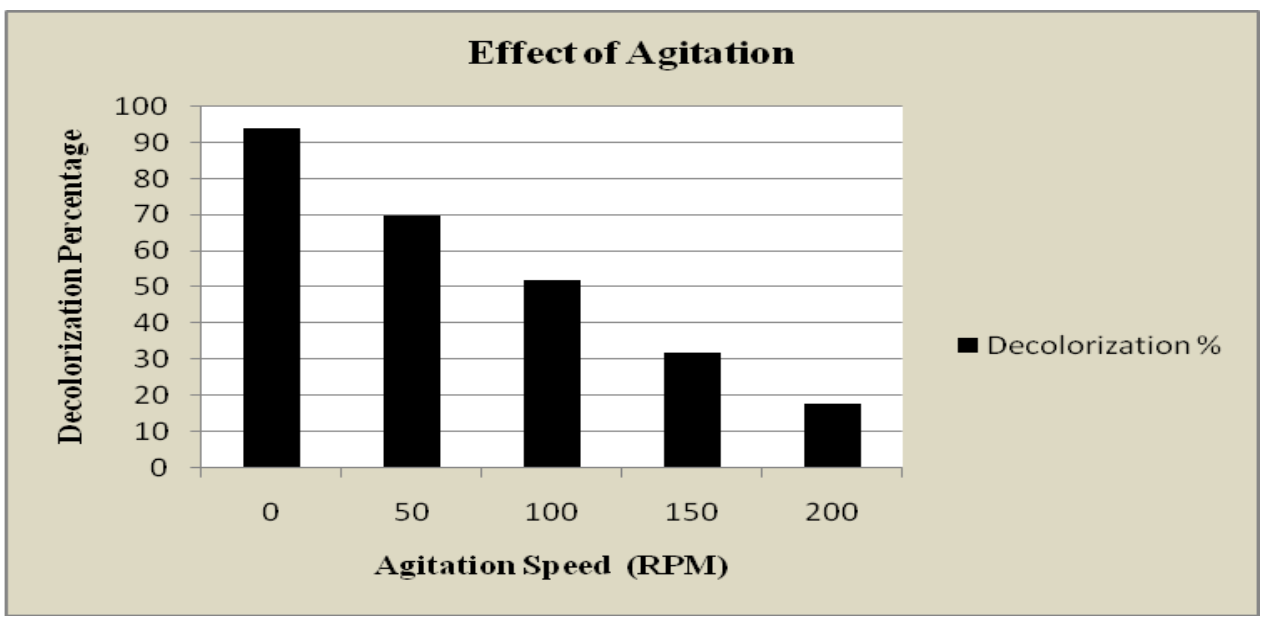

Fig.9 Effect of dye concentration on bacterial biomass of E. coli strain AKI-2

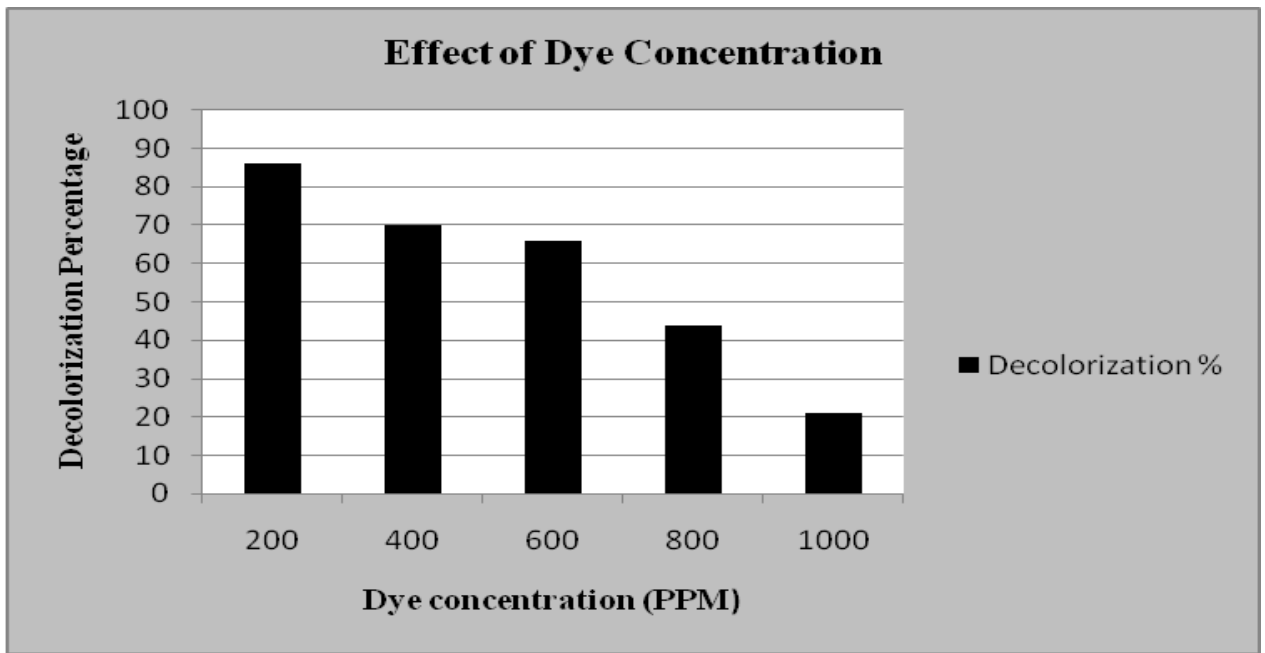


Fig.10 Effect of dye concentration on decolorization of evans blue by E. coli strain AKI-2

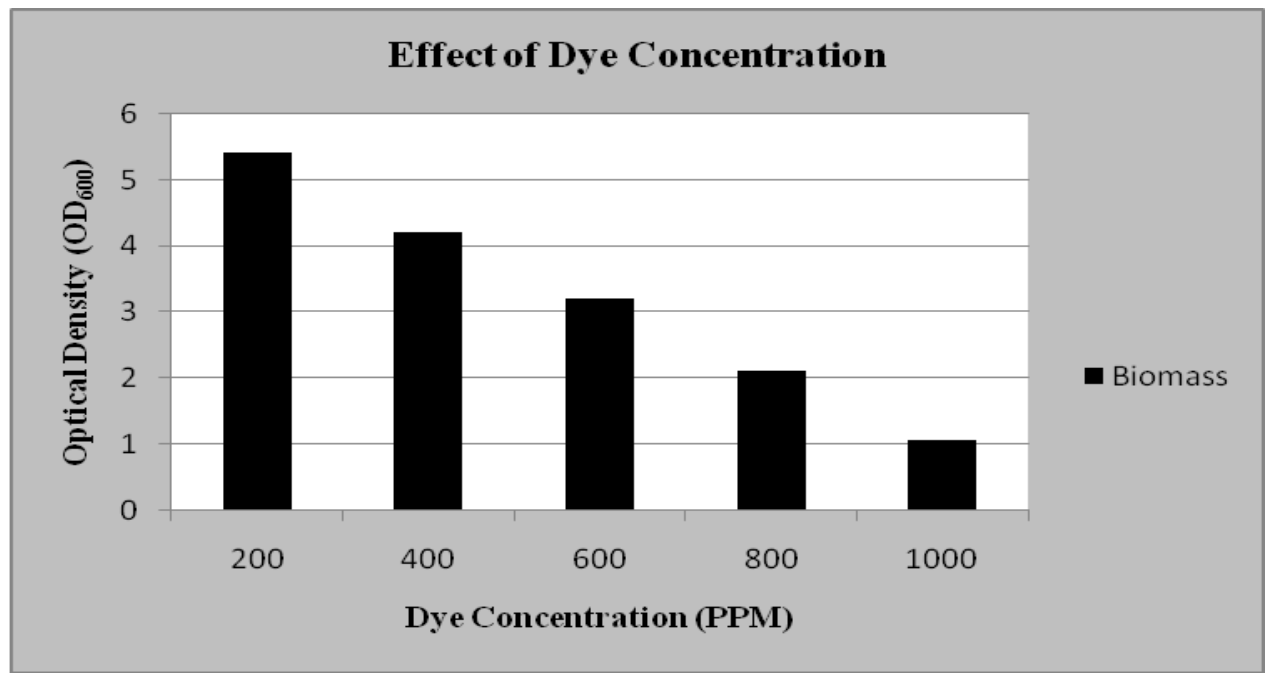

\section{Effect of dye concentrations}

The influence of different dye concentrations $(0-1000 \mathrm{ppm})$ were analyzed on bacterial biomass and decolorization ability of E.coli strain AKI-2. The results shown in Fig 7 and 8 revealed that the decolorization rate increased linearly with increase in initial dye concentration upto $100 \mathrm{ppm}$. As the dye concentration increased in the culture medium, a decline in color removal was attained. At high concentration (1000 ppm), Evans blue greatly suppressed both bacterial biomass and decolorization ability.

\section{Effect of agitation speeds}

Microorganisms vary in their oxygen requirement. The effect of various agitation speeds $(0-250 \mathrm{rpm})$ on the bacterial growth and color removal capacity of E.coli strain AKI-2 was studied at $35^{\circ} \mathrm{C}$ after $24 \mathrm{~h}$ of incubation. The decolorization ability of the isolate was found to be maximized at static conditions. Shaking conditions highly repressed the decolorizing ability of E.coli. In contrast, the bacterial biomass was found to be maximized when incubated at $200 \mathrm{rpm}$ (Fig 9 and 10).

\section{References}

Aksu, Z., N.K.Kilic, S.Ertugrul and G.Donmez. (2007). Inhibitory effects of chromium (VI) and Remazol Black B on chromium (VI) and dye stuff removals by Trametes versicolor. Enz. Microbiol. Technol., 40:1167-1174.

Hemapriya, J and S.Vijayanand. (2013). Bioremediation of Structurally different textile dyes by a novel bacterial consortium.

Int.J.Curr.Microbiol.Appl.Sci., 2(11):212- 226.

Hemapriya, J., Rajesh Kannan and S.Vijayanand. (2010). Bacterial decolorization of textile azo dye Direct Red-28 under aerobic conditions. J.Pure Appl.Microbiol., 4(1):309-314.

Husseiny, S.M. (2008). Biodegradation of Reactive and Direct dyes using Egyptian isolates. J. Appl. Sci. Res., 4(6):599-606.

Kalyani, D.C., A.A.Telke, R.S.Dhanve and J.P.Jadhav. (2009). Eco-friendly biodegradation and detoxification of Reactive Red-2 textile dye by newly isolated Pseudomonas sp. SUK1. J. Haz. Mat., 163:735-742.

Koyuncu, I. (2002). Reactive dye removal in 
dye/salt mixtures by nano filtration membranes containing vinyl sulphone dyes: Effect of feed concentration and cross flow velocity. Desalination., 143:243-253.

Nigam. P., I.M.Banat, D.Singh and R.Marchant. (1996). Microbial process for the decolorization of textile effluent containing azo, diazo and reactive dyes. Proc. Biochem., 31(5):435-442.

Pearce, C.I., J.R.Llyod and G.T.Guthrie. (2003). The removal of color from textile wastewater using whole bacterial cells - A review. Dyes. Pigments., 58:179-184.

Sawhney, R. and A.Kumar. (2011). Congo Red (azo dye) decolorization by local isolate VT-II inhabiting dye-effluent exposed soil. Int. J. Environ. Sci.,
1(6):1261-1267.

Shyamala, A., J.Hemapriya, K. Vadakkan and S.Vijayanand. Bioremediation of Methyl Orange, a synthetic textile azo dye by a halotolerant bacterial strain Int.J.Curr.Research.Academic review. 2(8): 373-381.

Tang, W.Z. and R.A.Chen. (1996). Decolorization kinetics and mechanisms of commercial dyes by $\mathrm{H}_{2} \mathrm{O}_{2} /$ iron powder system. Chemosphere., 32:947958.

Zhang, F., A.Yediler, X.Liang and A.Kettrup. (2004). Effect of dye additives on the ozonation process and oxidation byproducts: a comparative study using hydrolyzed $\mathrm{C}_{1}$ Reactive Red-120. Dyes. Pigments., 60:1-7.

\section{How to cite this article:}

Aswin Kumar, S., N. Arunagirinathan, S. Vijayanand, J. Hemapriya and Indra, V. 2017. Bioremediation and Detoxification of a Textile Azo Dye-Evans Blue by Bacterial Strain AKIP2. Int.J.Curr.Microbiol.App.Sci. 6(5): 2687-2694. doi: http://dx.doi.org/10.20546/ijcmas.2017.604.313 